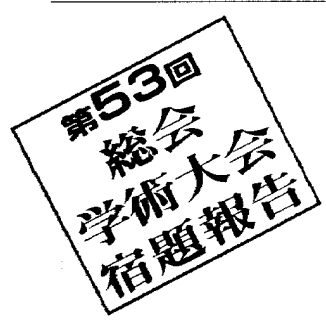

会期：平成 9 年 4 月 5 日

会場：パシフィコ横浜会議センター

消化管X線検查の変遷と画像技術

堤 直葉

越谷市立病院放射線科

\title{
The Chronological Improvement of Gastrointestinal X-ray Examination and the Imaging Technology
}

Suguha Tsutsumi

Department of Radiology, Koshigaya Municipal Hospital

\section{1.はじめに}

33年前，私は診療エックス線技師学校を卒業して阪 大病院に就職した。当時, 東芝のX線TV 1 号機が稼働 していた，そのTVのアルミニウムの軽量カセッテが 搬送中によく詰まり，私はよくドライバーで吅き落と していた，手や白衣はアルミニウムの粉で污れた。当 時, 消化管検查は蛍光板方式 (当時, 暗室透視と呼ん でいた)で，技師は透視室の外で，医師が斜位だと言 えばそれをイメージして条件をあわせていた，X線TV になり，斜位も正面も実際とは違っていた。暗順応の 眼鏡や圧迫用のディスティングトールが使われてい た，夏は透視室に氷柱が立てられ，汗でフィルムに指 紋が付くのを気にしていたのが思い出される。フフィル ムは手現像の時代で，阪大病院には日本には珍しい大 きいハンガータイプの自動現像機が稼衝していた。ま もなくローラータイプの自動現像機が入った。 その小 ささに驚き，条件を加減することができないのにもお びえた．その時にポータブルの写真を真っ先に流した 先輩を尊敬したものである。

約40年前, 日本で消化管の二重造影法が開発さ机 た。1975年, 越谷市立病院に就職した私は, 白壁一門 の内科医と働くようになり，透視時間の長さや病変の 描出への執念を理解することができた。「もっと透視 が見えたら，もっと良い写真が撮れたら，もっと小さ な病変が見つかるのに」と考えた先達の熱い思いが試 行錯誤を重ねながら実現されてきた。しかし，X線発 見100年を待たず，1994年末に白壁彦夫先生が逝去さ れ残念である。

今，なぜ消化管X線検査技術なのか，なぜ堤が宿題 報告しなければならないのか.

$\mathrm{X}$ 線発見の次の 100 年は「質」の時代と考え, 私なり の消化管X線検查技術へのこだわりを理解していただ き,「消化管X線検査技術の最適化にに向けて, 役立ち たい.

\section{2. 消化管X線検且について}

消化管X線検査について私の考えを述べたい．日本 における消化管X線検査は(1)検查方法の確立がなされ ていること. (2)読影理論の確立がなされていること.

(3)造影剂とその用法の完成度が高いこと.つまり空気 とバリウムの高品質の商品が市販され，使用法の標準 化が進んでいること. (4)画像技術は撮影系と透視系に 分けられ，両者の技術革新も目覚ましいと私は考えて いる.つまり消化管X線検查は完成度が高いと結論で きる。ではなぜ，今，消化管X線検査なのか．

「もっと見えたら」の時代から長い年月を経て，X線 管の大容量小焦点化，画像記録系の進歩や多様化のな か, 「画像, 被曝, 経済性等のバランスのとれたシス テム」を選択する時代になったと考える。つまり最適 化である．最適化を難しくしているのは，(1)診断する 側から「ここまでの画像なら診断できる」という画質の 下限が示されていないこと. (2)読影理論が確立されて も，診断能の差が大きいこと．(3)検查方法が確立され ても，検査する側の技術の差が大きいこと．また検査 技術の上達は容易ではないこと等が挙げられる。一 方，装置等の更新には多額の費用がかかり，機種間の 性能の差が大きくその価格差が大きい。そそういう現状 は消化管検査に限らず医療全体が抱える問題であり， その現状を容認している健康保険行政にまでさかのほ る。装置の性能も，検查技術の差も保険点数に反映し ない，今後ますます少子高齢化社会となり医療経済が 厳しくなるなか質」を保っていく医療人の努力は医療 人個々の質の向上にかかっている。

\section{2-1 消化管X線検査の推移について}

上部消化管(胃)X線検查は内視鏡の技術革新によっ て全国的に検查件数が減ってきているといわれてい る. 越谷市立病院 (以下, 越谷)でもFig.1のように胃X 線娭查は減り, 注腸検查が増え, 内視鏡はもっと増え 


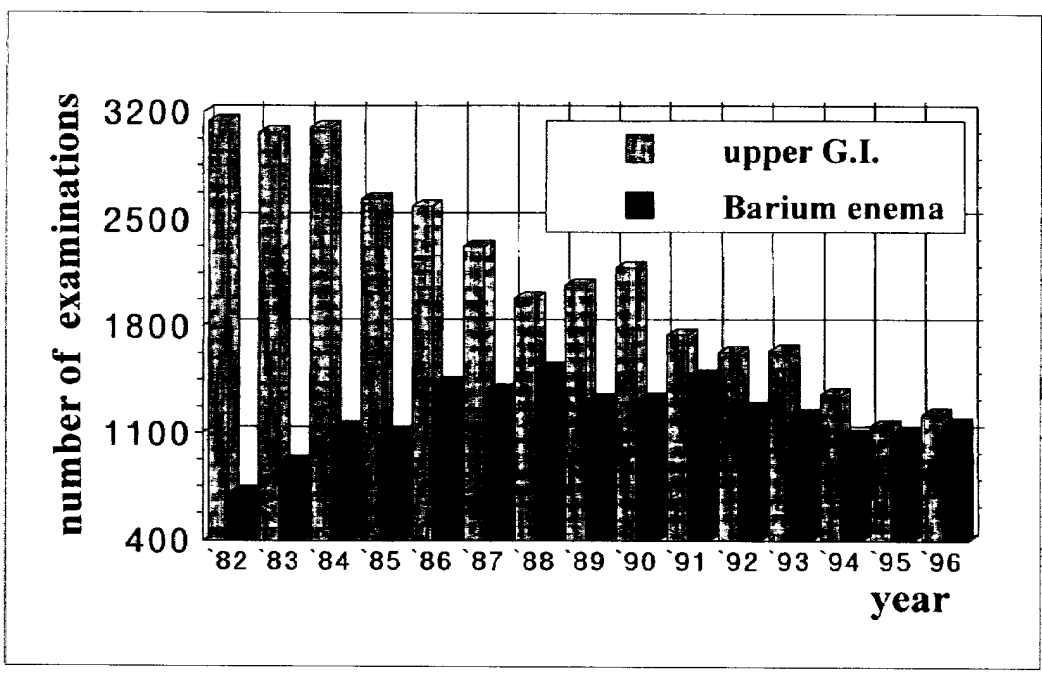

Fig. 1 A chronological trend of $X$-ray examinations for the gastrointestines at Koshigaya Municipal Hospital. Number of $X$-ray examinations for upper G.I. is declining nationwide.

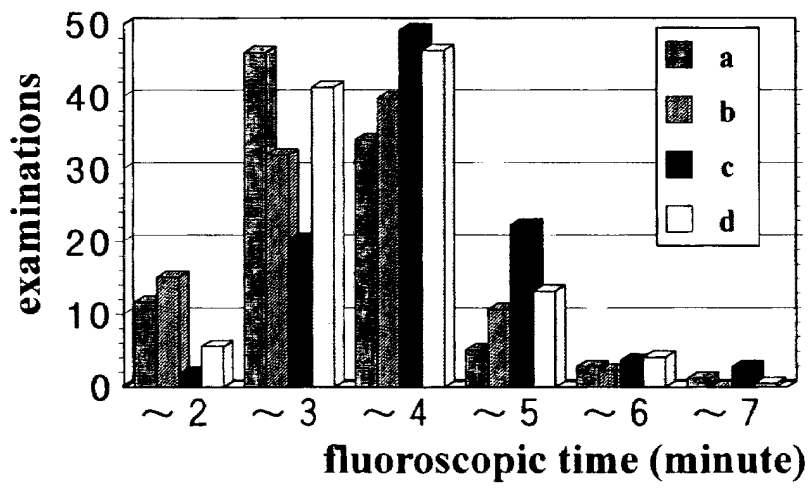

Fig. 2 Comparison of upper G.I. examinations with a remote controlled over table tube type X-ray TV in fluoroscopic time among 4 radiologists at Han-nan Chuoh Hospital ('76-'77). 8.4 radiographs per examination on average were taken The fluoroscopic time was relatively shorter.

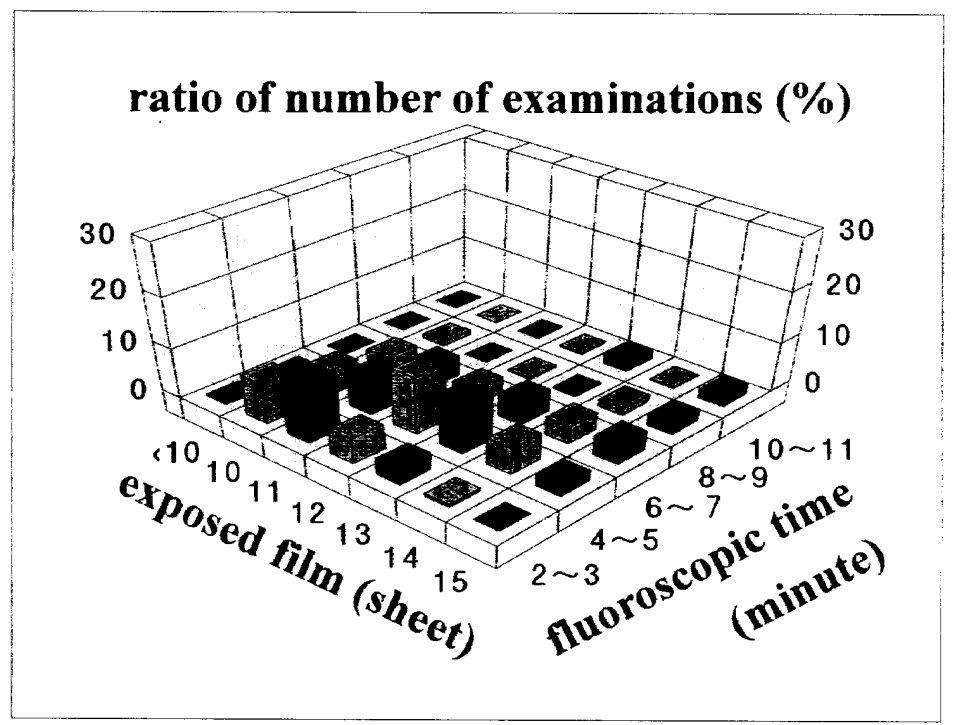

Fig. 3 Number of exposed films and fluoroscopic time taken in upper G.I. examinations with the local under table tube type $X$ ray TV at Koshigaya Municipal Hospital ('80-'81).
ている。しかし, 胃X線検査は, 病院 で減っていても検診施設や検診車では 減っていないといわれている，検査件 数が減ったとしても，まだまだ国民の 医療被曝に占める消化管検査の割合は 高い.

\section{2-2 胃X線検査の撮影枚数と透視時間 の相関について}

胃X線検查の撮影枚数と透視時間は 患者の被曝線量に大きく影響する。

Fig.2は阪南中央病院のオーバーテーブ ルチューブ(以下，オーバーチューブ) $\mathrm{X}$ 線TVを使った胃X線検查の透視時間 を示したもので a, b， c，d，4名の放 射線科医のものである. 撮影枚数も少 なく，全員の平均は8.4枚だった。透視時間は 3〜4 分台に集中していた。今加ら 20 年前で, 三相の装置で，0.8mm焦点の高速回転のX線管 を使っていた．粘着テープ式のカセッテレス方 式で，フォトタイマは濃度が合わず，いろいろ と技師たちが工夫した。

Fig.3には越谷における胃X線検查の撮影枚数 (使用フィルム数) と透視時間の相関について 図示した。調查期間は1980１981年。装置は 近接アンダーテーブルチューブ(以下，アンダ 一チューブ) X線TVで，カセッテ方式，三相装 置で普通回転X線管，透視条件は透視電圧が自 動で，透視電流はマニュアルで合わせていた。 精密娭査等は除き，熟練内科医の検查のみ集計 した.

Fig.4にはアンダーチューブ，オーバーチュ 一ブ両方あわせた件数を示した。調査期間は 1994 1995年である。越谷では透視時間の長 さは装置のタイプより術者(医師)の個人差が大 きいことが分かった，越谷では開院時より透視 時間を記載している。

Fig.3，4を比較すると透視画像は良くなった が透視時間は長くなっている。前者は近接夕 イプ，後者は遠隔操作タイプである，後者は㮩 者の被曝は減るが，患者の被曝は増える傾向に ある。

Fig.3の装置のX線透視は線量が低く画質も悪 い. Fig.4では高線量高画質であった，初期のメ タルII.I゙使われていて，透視条件では前者の2 倍くらいだったが，線量計で測っていない． 


\section{2-3 近接アンダーチューブX線TVの画質改善} について

20数年前, 開院時越谷に設置された精密検 診用X線TV, KBTはカセッテ方式で, 撮影は $\mathrm{X}$ 線管焦点 $1 \mathrm{~mm}$ のとき，管電圧 $85 \mathrm{kV}$ を使用す

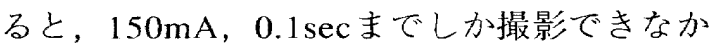
った，装置の形状により高速回転X線管が取 り付けられなかったからである。これでは患 者が大きいと撮影できないので $2 \mathrm{~mm}$ 焦点にな った。それでもカセッテは手動で撮影の良い タイミングを逃さなかった。この装置の透視 条件はX線管電圧だけが自動で，管電流は患 者に合わせ技師が設定していた。透視電流は 標準体型では0.5mAくらいだった，残像も多 くコントラストの低い状態で使って抢り，透 視条件を上げても効果が低かった。

1979年，同上のTVと同じものをメーカに作っても らった。相 6 パルスは同じでX線管は高速回転，焦 点寸法は $0.8 \mathrm{~mm}$ (単峯性)だった。ターゲット角度も 小さくして容量を大きくした．撮影条件は $85 \mathrm{kV}$ では $400 \mathrm{~mA}, 0.1 \sec の$ X線がでた。しかし，カセッテ送り は自動にしたため，前の機種に劣り，X線管の回転数 を落とさないため透視中でも 1 分間に 1 回駆動をかけ て，早くX線が出せるように工夫がされた。そのこと を本会の関東東京部会で発表した。

その時の 2 機種のMTFをFig.5に示す，a, b は機種 を表し，aは古い機種である，MTFは速写部より $5 \mathrm{~cm}$ の位置に解像力チャートを置き測定した。感度の違う 堌感紙を用いたが $\mathrm{a}$ 機種では差がでなかった，患者が 大きいと a 機種では $2 \mathrm{~mm}$ 焦点を使用しなければならな いので両機種の差が広がった。 b はYSF-20といい, 老朽化しながら今も稼働している。

昨年(1997年)，越谷に新しいアンダーチューブX線 TVが設置された，熊倉先生 $1.2 \%$ 考えでできた装置， GI SCOPEである. 当然カセッテレスでインバータタ イプ，透視時には撮影用グリッドが退避する。全体と して散乱線の少ないシステムだ。フォトタイマも良く なっているがユーザの情報が入ればもっと改良できる 設計だ.

消化管X線唡査では装置の低搪大率が議論されるが X線管焦点を小さくすれば解決できる，時には拡大効 果も期待できる。また大電流だと短時間撮影ができ， より鮮明な写真ができた，YSF-20では，1mmでもフ イルムと患者を密着させたいため無理をし，トラブル が続出した。システムとしての画質が私の頭になかっ たようだ。

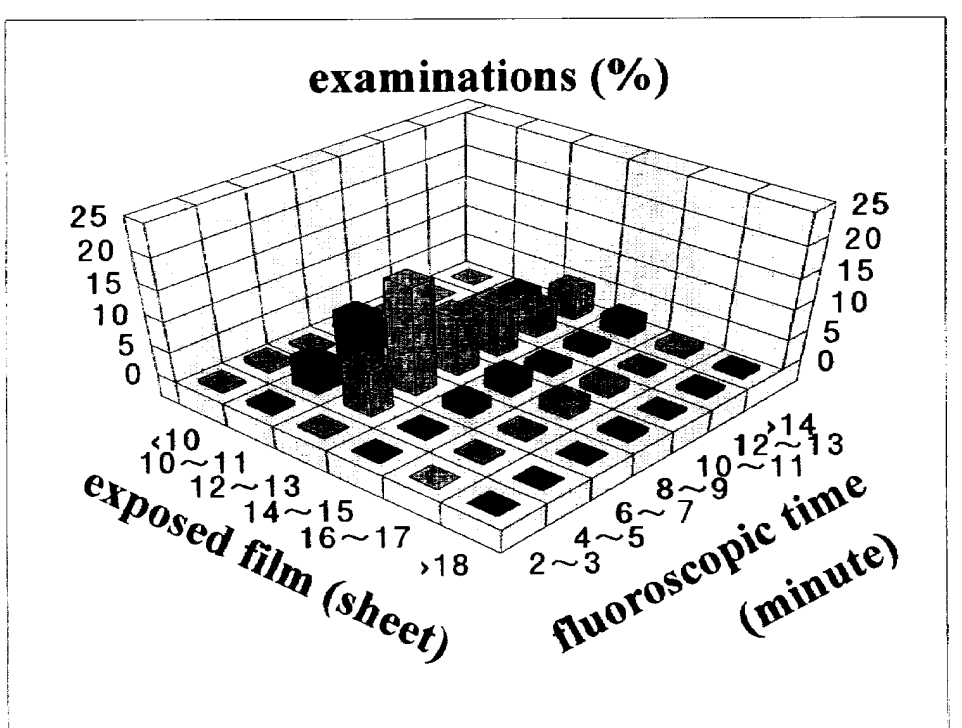

Fig. 4 Number of exposed films and fluoroscopic time taken in all upper G.l. routine examinations with two X-ray TV systems at Koshigaya Municipal Hospital ('94-'95).

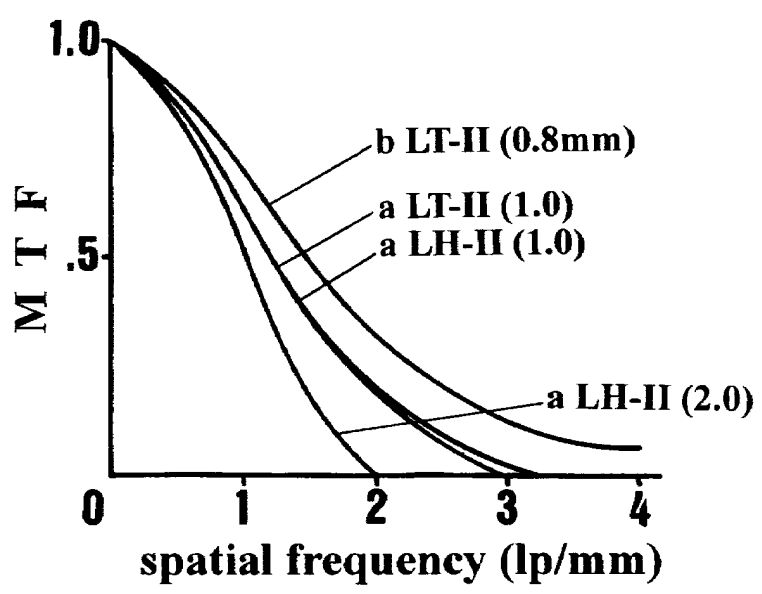

Fig. 5 A comparison of two local X-ray TV systems in MTF ('79).

(a) Earlier model (conventional type).

(b) The latest model

The figure in the parenthesis indicates the focal spot size in $\mathrm{mm}$.

\section{3. 検直における撮影系の画像技術}

私の考える撮影系の画像技術とは簡単にいえば，装 置と記録系，X線被曝である。装置はX線TVとし，記 録系はアナログ，ディジタルに区別されるが，ここで はアナログ画像を主に考える。自現機処理はフィルム の薄膜化で濃度はほぼ安定した，処理時間とフィルム の改良が本学会で研究されたが今は少ない。

\section{3-1 撮影系実態調査班の資料からX線管について}

本学会では後に述べる増感紙-フィルム系の転換期 に対応するため1980年に実態調査班が作られだー6). この班が後の第一次撮影系実態調查班となる．私は 3 


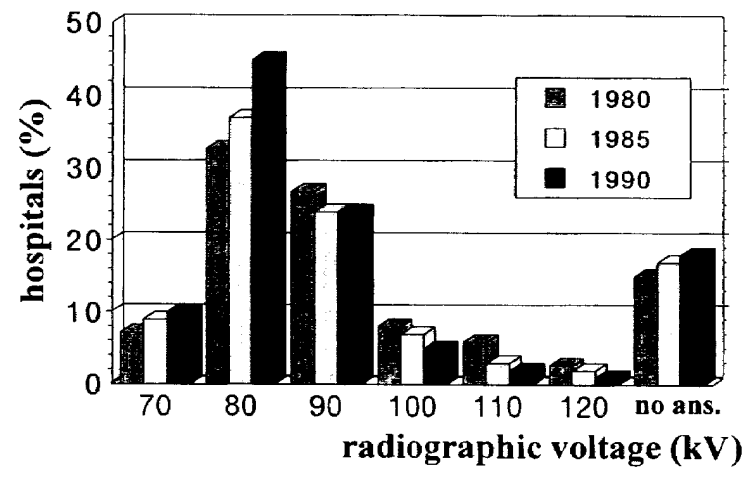

Fig. 6 A trend of the voltage of the $X$-ray tube in the upper G.I. examinations. The voltage of the $X$-ray tube was read from the control panel. The data of Figs. $6,8,10,12$, and 13 were acquired from the field survey.

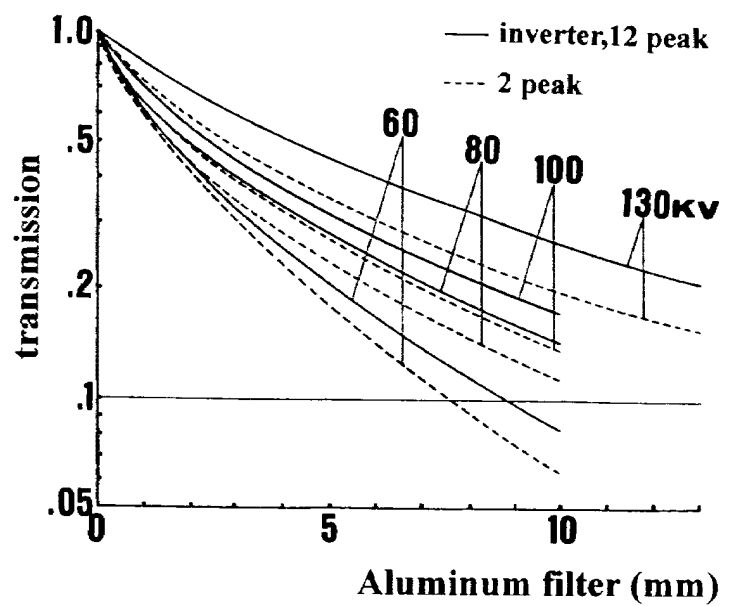

Fig. 7 The comparison of radiographic voltage with aluminum transmission curve. This was measured in a narrow beam. The $X$-ray TV systems equipped with an inverter type are popularly used these days.

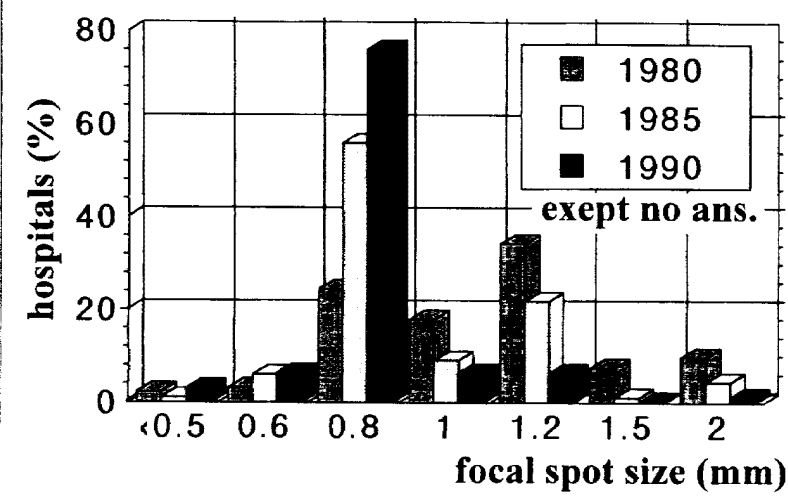

Fig. 8 The focal spot size of the $X$-ray tube (nominal value) is being consolidated.
回まで関係した。第三次はディジタル化への移行を考 え，X線撮影だけでなく，X線CT， CR，DSAを増や した1995年に続かなかったのはたいへん残念なことで ある。この結果の一部は1991年にRSNAで発表した。 世界的にみても資料洒值があったと考えられる。1995 年のX線撮影系の調查があり班長の好意により結果走 いただいたが，その結果が本紙に揭載されてないため 図表にしなかった。

実態調査のアンケートの条件は成人男子，腹厚が $18 \mathrm{~cm}$ の胃部二重造影正面背臥位撮影とした。

Fig.6に3 回の実態調査による撮影管電圧の推移を 示した。四の撮影電压は装置の表示值であり，電圧波 形を考慮に入れていない生データである。 $85 \mathrm{kV}$ 付近 が多かった。Fig.6，8，10，12，13は実態調査のデー 夕を用いた。

Fig.7は撮影電圧の波形つまり電源, 整流方式によ る線質の差を示す目的でアルミニウムの透過曲線を作 成した。実験は東芝の工場で，測定器はビクトリーン のRメータ，測定はnarrow beamで行った。散乱線を含 まないデータなので実際の使用時とは異なる、X線管 は同一のものを使用し，供給電源は良い状態での結果 である。現在は単相装置はほとんどなく，インバー夕 が主流である。

撮影の命といえるX線管は陽極回転速度の3 倍高速 化により，0.3/0.8mmの焦点を実用可能にした。Fig.8 はX線管焦点サイズ(公称值)の分布で統一化が進んで いる．古典的焦点サイズ $1 / 2 \mathrm{~mm}$ は過去の技術となっ た，将来ディジタル化の画像技術を用い，もっと小焦 点化が進んでほしい，放射線被曝を増やさないで画質 向上を図るには，X線管の小焦点化が一番効果的だ。 Fig.9に焦点の規格の寒態を示す7!，X線管焦点サイズ は公称值が通用しているが，実效焦点との差は大き く，それはJISの許容範囲からもわかる．写真の画質 は焦点の面積に依存するので縦軸は焦点面積で表し た、許容範囲の最大值と最小值の差はあまりに大き い. 画像へのこだわりのあるユーザは小さい焦点のX 線管が届くようにX線管の焦点写真をメーカに請求し たりして、こだわりを表現したい.

X線管の大容量化をまとめてみた。

・回転陽極を 3 倍回転にすることによって1.7倍に。

・ターゲット角度を小さくすることにより1.4倍に (アンダーチューブ，4切の照射野で17゙から $12^{\natural} に$ 変えた場合)。

・入力波形による効率化(単相全波整流を三相，イ ンバータに換える)現場では電源事情もあり一概 には言えないが効果は大きい.

この実態調査ではX線管の総濾過のデータが正しく とれなかった。画質，被曝のバランスを考えるにはど 
うしても欲しいデータだった。

撮影時間，つまり夕イマは $0.1 〜 1$ 秒の間に大半はは いる．回答にあった使用X線管のHUから考え，もっ と大電流を使用することによりタイマを短くできる。

\section{3-2 増感紙-フィルム系について}

1975年，日本コダック株式会社のOGフィルムの出 現により，日本でも線フイルムのオルソクロマチッ クフィルム(以下，オルソ)化が始まった。 オルソフィ ルムの開発当初は高感度フィルムとして設計されてお り，増感紙-フィルム系の画質は従来のブルー発光増 感紙とレギュラーフィルムのシステム(以下，ブルー システム)より劣っていた，その当時越谷で，胃の精 密検診の増感紙-フィルム系について内科医よりクレ ームがついた。グリーン発光増感紙LanexRegularと才 ルソフィルムOGでは早期胃ガンの質的診断ができな い. 理由は陉凹の周りの浮腫の状態が分からない．骝 凹の形が違って写るということだった。そこでブルー システムのLH-II とNewRXで前者との比較がなされ， 後者が優れていた。その頃の画質が忘れられないユー ザがまだいる。

経済性で見たオルソ化はフィルムの価格は同じでも 増感紙が高価格で，フィルムチェンジャが価格の欠点 を補った。

Fig.10は増感紙-フィルム系の使用比率の推移，ブル ーシステムから稀土類のグリーン発光増感紙とオルソ フィルムのシステム (以下，グリーンシステム)への移 行はX線TVシステムでは早かった。

Fig.11は実態調査で頻度の高い増感紙-フィルム系の MTF. この眓ではグリーンシステムは，HR-4+オルソ フィルムの組み合わせが多く，ブルーシステムでは点 線のBM III+NewRXが多かった。この図は1990年に作 成したが，現在では同一感度でもMTFのすぐれたシス テムが市販されている。

Fig.12は穾態調査で使用されている増感紙-フィルム 系の相対感度を，ブルーとグリーンシステムに分けて その施設数比を示した。調査初期に多かったMSクラ ス増感紙+普通感度レギュラーフィルムNewRXを基 準とした。

Fig.13はFig.12のデータを用いて推定線量を計算し たもので，増感紙-フィルム系の感度が同じでも施設 間の線量の差は大きかった。これはアンケートからの 推定であるため，実際の線量差は分らないが品質管理 が必要であることは明らかである。

次は，1978～1982年に本学会に発表した増感紙の 変性についてである。増感紙の保護膜の損傷によりそ の部分が減感する事態が全国的に発生した。原因には フィルムからの影響もいわれた。フィルムチェンジャ

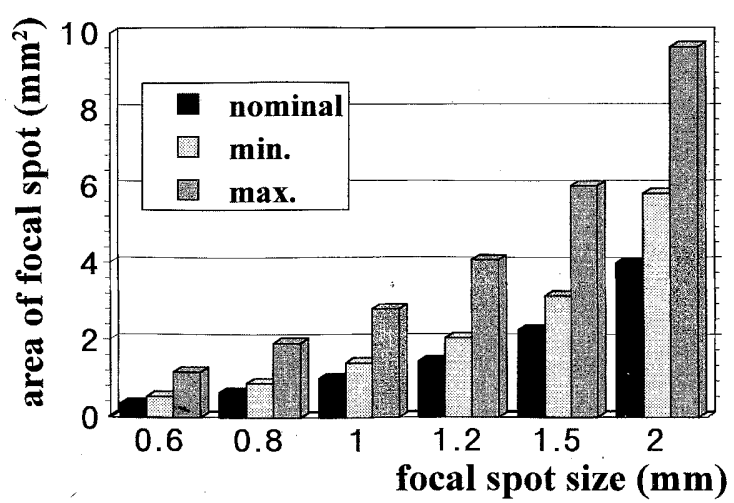

Fig. 9 The difference of the focal spot size between the nominal value and the tolerance by JIS standard. The nominal focal spot size is much different from the effective focal spot size. The vertical axis shows the area of the focal spot because the image quality much depends on it.

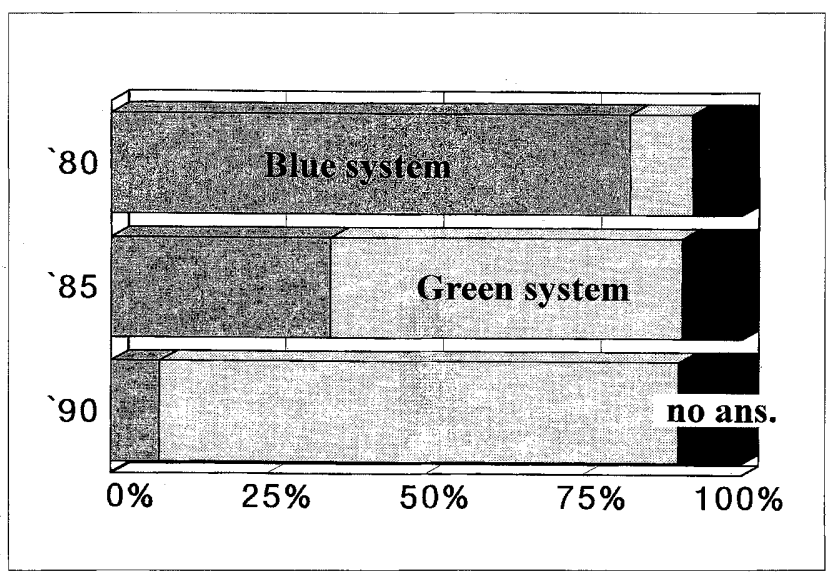

Fig. 10 A trend of the X-ray intensifying screens installed in X-ray TV systems. The green-emitting screens had been employed more earlier than other $\mathrm{X}$-ray systems.

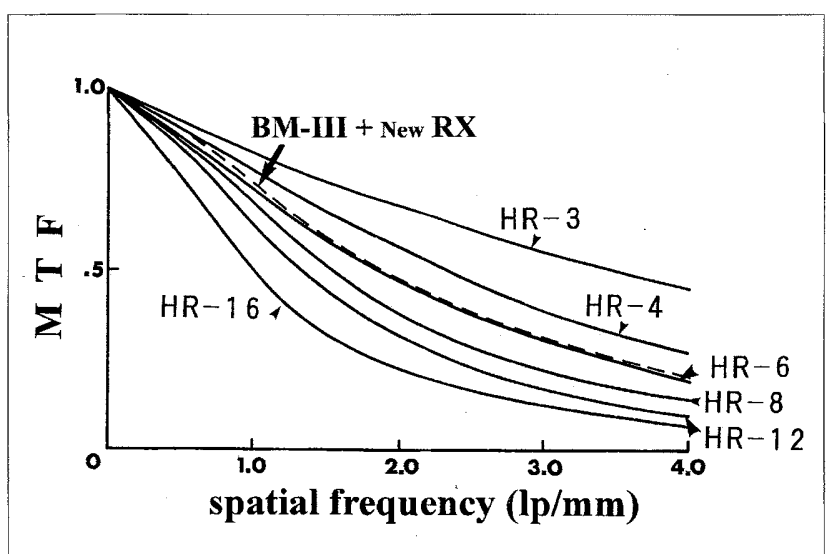

Fig. 11 The comparison of the MTF of the intensifying screens and X-ray film combinations popularly employed in X-ray TV systems in the field. The HR-4/orthochromatic film combination among green systems and the "BM-III"/"NewRX" regular film combination among blue systems (a dotted line) were mainly used in the field ('90). 


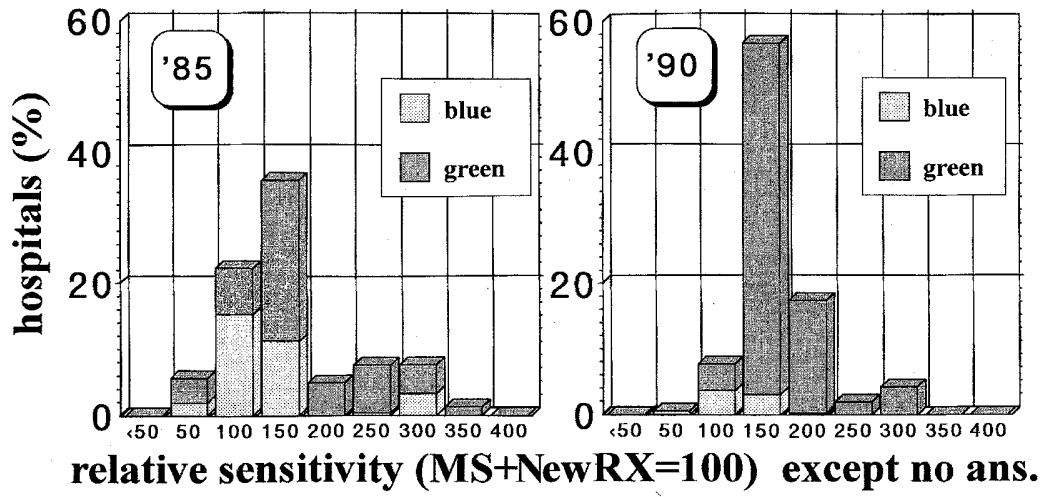

Fig. 12 The distribution of the relative speed of the intensifying screens and Xray film combinations employed in X-ray TV systems in the field. The relative speed is calculated based on the "MS" intensifying screens and "NewRX" combination as 100 .

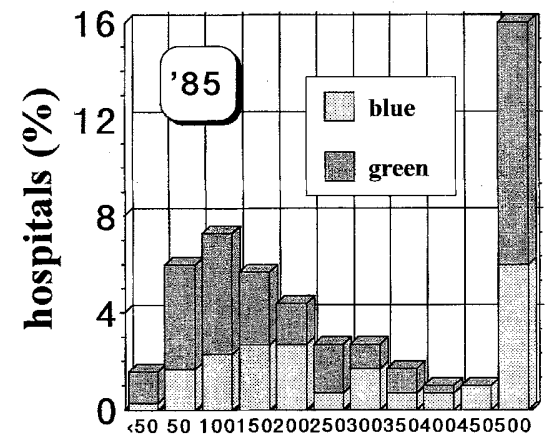

calculated exposure

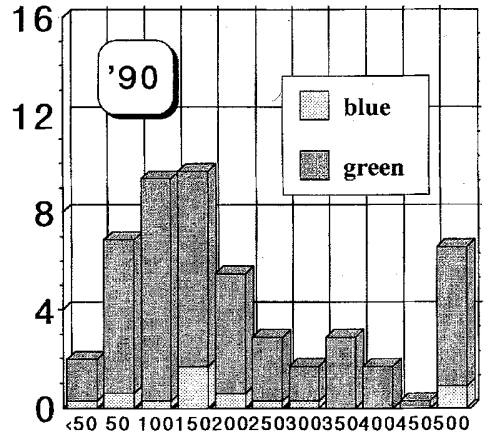

except no ans.
Fig. 13 The distribution of calculated exposure in an upper G.I. double contrast examinations based on the data of Fig.12. The calculated exposure varies from site to site even with the same relative speed combination.
タイプの多いX線TVでは多発 した。変性はフロント増感紙で 顕著たった。メーカ側の原因の 説明と対応についてはケースバ イケースであったがこの事件は 発展途上の一幕だった. Fig.14 はフロント増感紙の写真であ る。この変性は画質向上のため 保護膜を薄くした商品で多発し た.フイルムチェンジャの普及 によりフィルムを挟んでいたイ ンターリーブドペーパーがなく なろうとしていた時期たうた。

フイルムチェンジャタイプの $\mathrm{X}$ 線TVの初期の機種では, 増 感紙とフィルムの密着に時間が かかり，X線㝍真の鮮鋭度が悪 くなった。1983年に埼玉の支部 会で発表した。Fig.15に示す。

図の縦軸，左はハウレットチャ 一トの読み值と, 右は解像力子 ヤートの読み值，横軸はフィル ムが装填されてからの経過時間 (秒)である。サイクル時間が 6 秒であることを考えると密着不 良のまま撮影がされていた，当 時のメ一カの増感紙-フィルム の密着度の測定は，細かい針金 の網で，それが当時の「品質」で

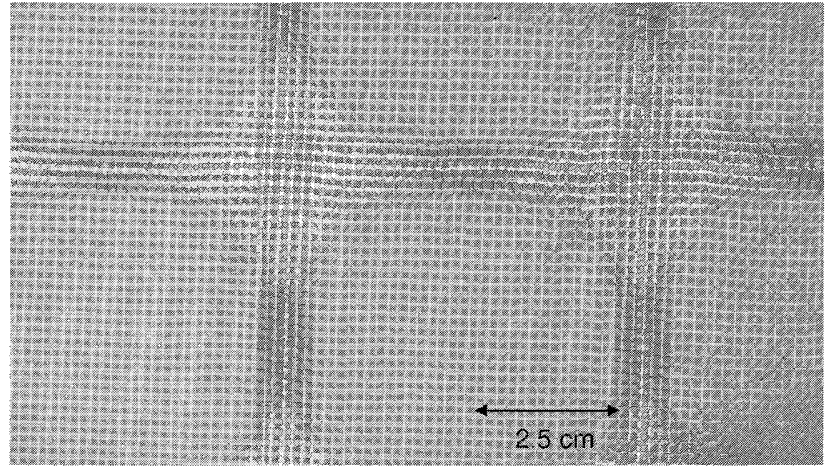

Fig. 14 The deterioration of the intensifying screens reported in '78-' 82 in this society. The protective layer of the intensifying screens was damaged and the surrounding area was dissensitized. This problem happened nationwide, especially in the screens installed in the X-ray TV systems.

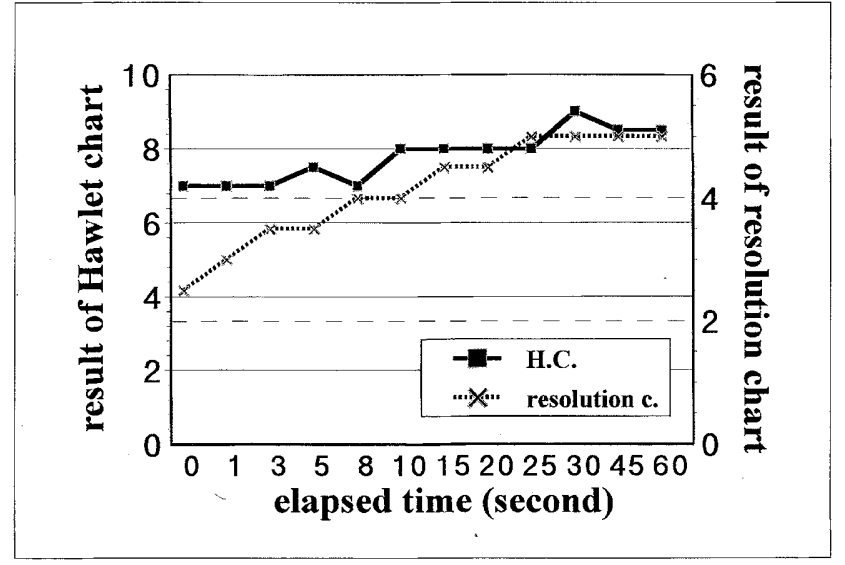

Fig. 15 An influence of the contact between the intensifying screens and the X-ray film in X-ray TV systems ('83). The early model of film changer type equipment needed more time to make a good screens-film contact, therefore, got a poor image in sharpness. The left vertical axis shows the result of Hawlet chart, and the right vertical axis shows the result of resolution chart. The horizontal axis shows elapsed time (second) after the film was set up in film spot device. 
あった。カセッテからカセッテレスへの転換 は，ユーザの需要に支えられ現在の品質とな った。フィルムチェンジャでは，力セッテの 時には大きい患者に高感度増感紙を使ってい た技術が発揮できなくなった。増感紙-フィル ムの密着板は高価なため, いくつも購入でき ないだろう。

X線フィルムのオルソ化は原料銀の高騰の 時期に速度を早めた。省銀は画質の低下を来 すのではないかとの議論が盛んにされた。そ こで，X線フィルムの含有銀を測ることを思 いついた。開業医で棚に眠っていたフィルム も届けてくださる万もいた。銀量は筑波の科 学技術研究所でフレーム原子吸光法を用いて 測定した8?.Fig.16はフィルム名，フィルムの使用期 限とフィルム含有銀量 $\left(\mathrm{mg} / \mathrm{cm}^{2}\right)$ である。銀量はフィル ム会社によって差があった。そ狄でもオルソフィルム は銀が少なかった。メーカ側からは銀量の節減は画質 を落とさない範囲内との説明だった。

当時のオルソフィルムでは，低濃度部示現が劣って いると考えたのでフィルムの特性曲線の低濃度部にお けるハウレットチャートによる視覚評価を行った。

Fig.17に結果を示した。視覚評伵は観察者により結果 が異なることが困難な点である。撮影条件は撮影管電 压 $70 \mathrm{kV}$ ，グリッドを使用して，ファントムはアクリ ル板 $10 \mathrm{~cm}$ とた。現在では当時よりオルソフイルム も増感紙も技術革新が進み，おいてきぼりのレギュラ ーフィルムでは勝ち日がない。

消化管X線検查には不可欠のグリッドは，慶応病院 の佐藤忠氏が胃透視を始めた1950年頃にはなかったと いわ机る。その画像が想像できない，余談になるが， バリウムは団子状で食べるもので, 撮影は, 立位充満 像,レリーフ像, 圧迫像, 重複撮影等であったと閏い た。グリッドの開発も長い物語になるが通り過ぎた い.はじかに書いた撮影用グリッドが透視時に待避す る装置は患者の被曝低減に役立つ、X線TVはオーバー チューブが増えて汎用型になってきた。造影剂もバリ ウム，ヨード製剤があり適正な撮影電圧が異なるた め,グリッドは簡単に取り替えられる機構が欲しい。

\section{4. 検㚗における逐視系の画像技術}

「透視がもっと見えたら」の蛍光板透視から始まった 消化管X線検査はイメージ増倍管（以下，I.I.)を用いた X線TVになってからも透視画像は良くなかった。その 後，X線TVの技術革新は目覚ましく，現在は透視のデ イジタル化が進んでいる。

自動輝度機構の信号の検出部はTVモ二タの中心部 に位置し，そこにバリウムがくれば過度にX線が出る

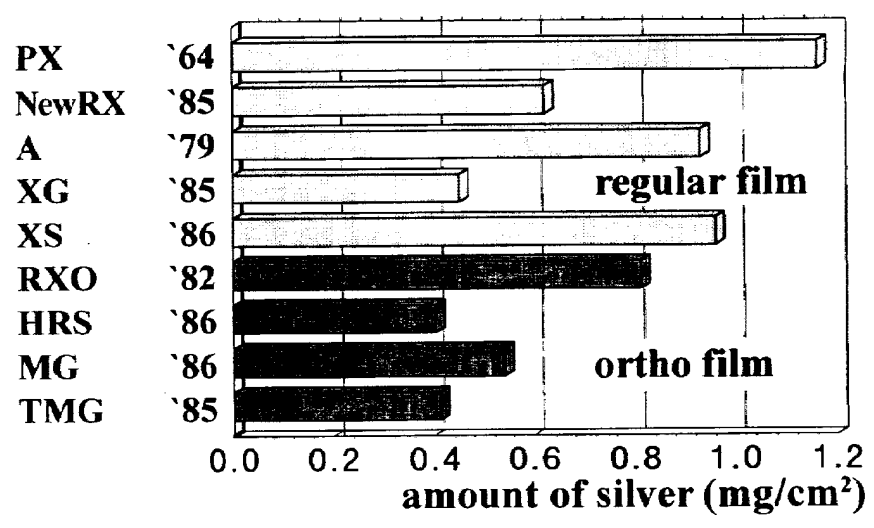

Fig. 16 The comparison of various types of $X$-ray film in an amount of silver in $\mathrm{mg} / \mathrm{cm}^{2}$ (' 88 ). The numbers adjacent to the film types show expiration years of the films.

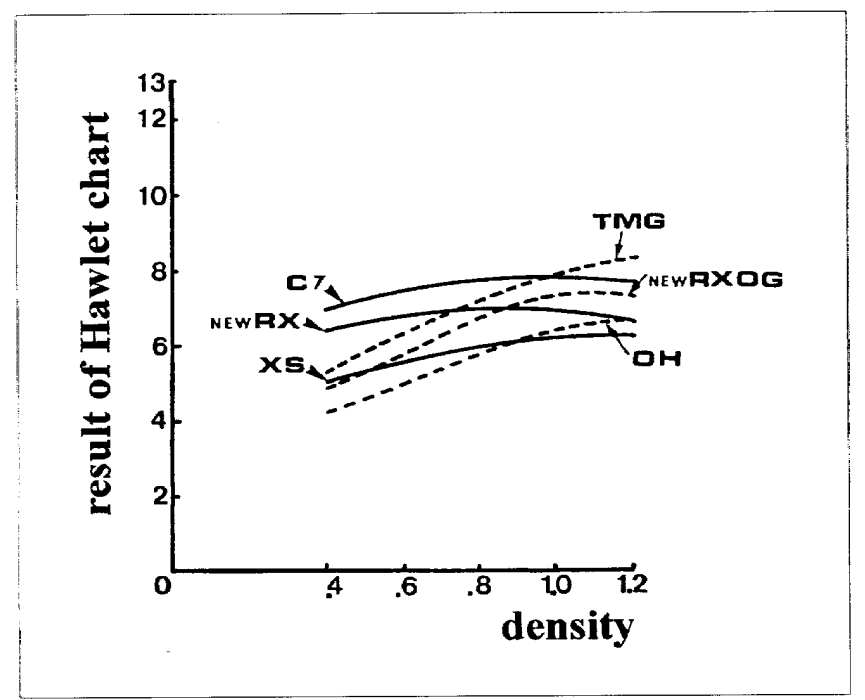

Fig. 17 Visual results of Hawlet chart at the low density area (exposure condition R.kv $70 \mathrm{kV}$ with grid, phantom: acryl $10 \mathrm{~cm}$ thick).

穖構で，他の技術革新からは考えられない状態がまだ 続いている、ユーザが高性能の自動化を望まないから と考える。Fig.18にX線TVの自動露出機構の検出部の 比較をしたａは現在用いられているもので単一検出 部で，透視にも撮影にも用いられている。20年以上前 から多検出部を作ってきたメーカもあるが全体に広が らなかった。それでも aよりは濃度のよくあう写真が できた。bは多検出部の一例だが，まだこれからと考 えられる。次に単一検出部の自動化機構を用いた装置 の無駄な被曝を考える。Fig.19にバリウムの画面被覆 率に対する線量比を示した。横軸の数字はTV画面の バリウム被覆率を示す。バリウムが多くなると透視条 件が高くなりすぎ，画面は光って見えにくくなる。こ れは無䭾な被曝である。バリウムがあってもないとき に比較して 2 倍以下の線量にしてほしい。

Fig.19はオーバーチューブの例であるが, アンダー チューブの場合はもっと無駄な被曝が増えている。ア

1998 年 3 月 


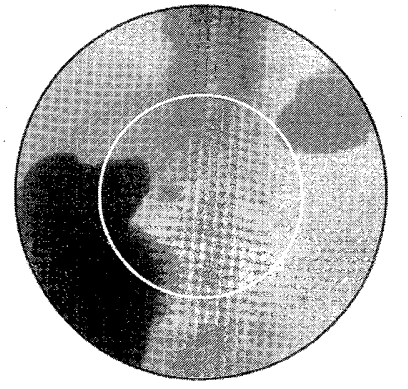

a

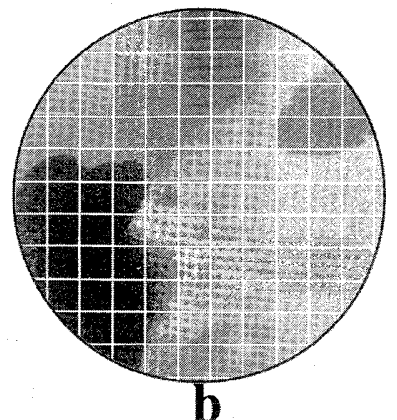

b
Fig. 18 The detectors of the automatic exposure control. (a) A single detector type.

(b) Multi-detector type.

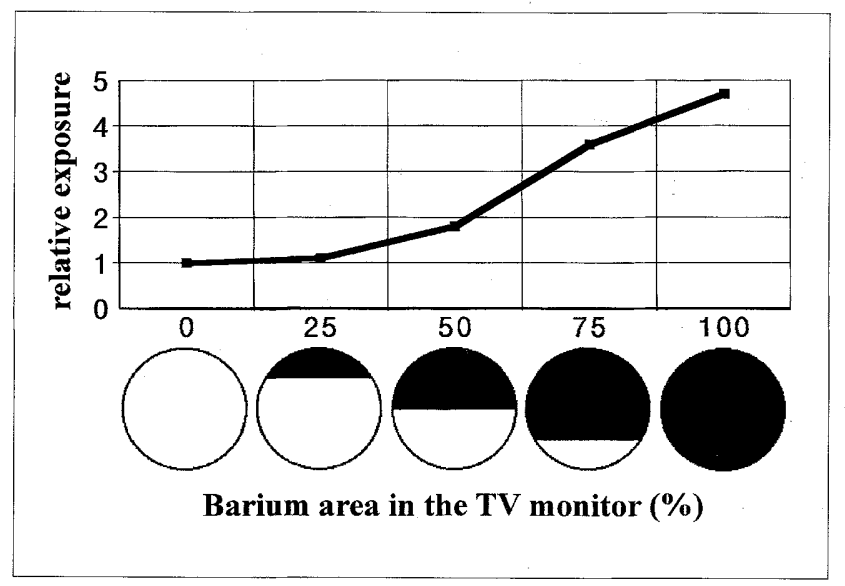

Fig. 19 The difference in exposures when the detector is covered with barium. The black area in the circle shows the barium area in the TV monitor.

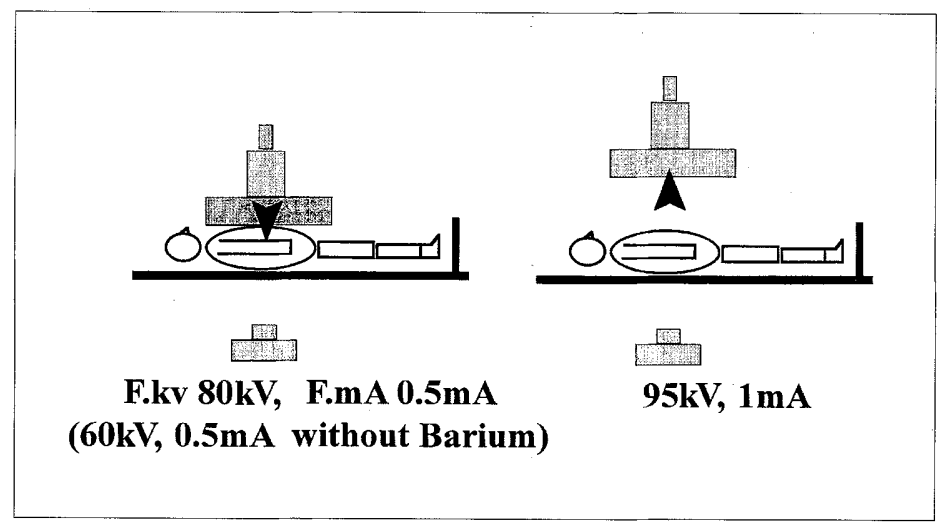

Fig. 20 Correlation between fluoroscopic conditions and the position of the detector using the under table tube type $X$ ray TV. The fluoroscopic conditions without barium is $60 \mathrm{kV}$, $0.5 \mathrm{~mA}$.

ンダーチューブは消化管用X線TVともいえるが，患者 の被曝低減には向かない.Fig.20はアンダーチューブ X線TVに扒いて，速写部の位置による透視条件の変化 について示した。患者は瘦せ形で二重造影正面の撮影 時である。バリウムがない状態では $60 \mathrm{kV}, 0.5 \mathrm{~mA}$
あった.アンダーチューブでは撮影時以外速 写部を患者から離しがちで検査する。患者の 体位変換が困難だからた。ててて，透視用のX 管焦点はほとんど $0.3 \mathrm{~mm}$ で離した方が病変は よく見える。なかには，検査技術が未熟なた め撮影時にも速写板を降ろさない医師がいる。

全国的にはアンダーチューブX線TVは減って いるが，消化管検査を重視する施設にはまだ設 置されている，TLDを用いた調査，実験では瘦 せた人ほど無駄な被曝が多い。つまり，特に大 きい患者の透視条件は装置の最高出力に近いた め，無䭾な被曝が少ないといえる。

Fig.21はアンダーチコーブX線TVで自動機 構により生じた過度なX線のため, TV画面が 光って見えなくなる場合の実験である，適正 な透視条件を超えると画面は明るすぎて見え なくなり，無䭾な被曝が増える。1990年に本 学会で発表した。

昔話になるが，阪大病院に蛍光板透視の装 置が稼働していた頃，TLDが日本に入ってき た。また国産のTLDも開発された。人骨入り のランドファントムは日本人より大きかった が学校から借りられた。そこで消化管X線検 查時の性腺線量を測ってみた. Fig.22に1977 年の論文 ${ }^{9,10)}$ の図を再現してみた。図は胃腸検 查撮影時の照射野の変化と性腺被曝線量につ いてで蛍光板透視とオーバーチューブX線TV の比較である。照射野の下縁と男女性腺の位 置関係に目を付けた研究は評価された。 $a, b$ は背臥位で, $\mathrm{c}, \mathrm{d}$ は腹卧位である. 蛍光板透

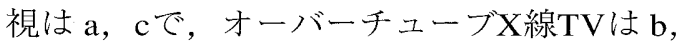
dである。

私は十余年前より, 関東のX線TV透視条件 を調査している。撮像管がCCDカメラに替わ る前からである。施設差が大きいため, 東芝 那須工場と共同で透視条件の視覚評価, 一部 ROC評価も行うことになった. 那須工場の実 験值と 2 施設の条件を線量で比較した。調査 施設のなかには，もっと高線量の施設もあっ たが除いたＩ.I.の高感度化，高画質化は著し いのに線量は減っていない,いや増えてい る。技術革新は画質の向上に寄与したのた。

Fig.23には自動輝度調整機構を使用した透視 条件を線量で比較した. 全部オーバーチューブタイプ で，1988年に測定した機種BVにおいて，アクリル $15 \mathrm{~cm}$ の条件を 1.0 とした。

Fig.24では透視画像の視覚評価に用いたチャートを 示した. $\mathrm{a}$ はQCツールのカッパメッシュ, bは自作の 
透視用チャート1である。矢印は実験に用い た小ビーズで大きさは外径 $2.1 \mathrm{~mm}$ である。c は解像力チャートである。

那須工場において，走查線 525本TVと 1,050 本TVの画像を視覚評価した。

Fig.25は, X線TV画像の評価時の実験図で ある、オーバーチューブタイプX線TVで，X 線管実効焦点: $0.45 \times 0.43 \mathrm{~mm}^{2}$, 散乱線除去グ

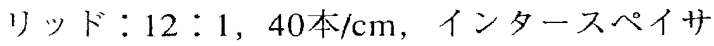
Al.でカバーレスタイプ. 天板は木製で厚さ $9 \mathrm{~mm}$.

Table 1 は東芝那須工場に扔ける，自動輝度 調整機構を使用した透視条件である。2 種のX 線TV系は同じX線管，発生装置を用いた。才 ーバーチューブタイプ, I.I.は9インチ，SIDは $110 \mathrm{~cm}$. 走查線 525 本 TVと 1,050 本 TVでIII.は 換えた.

Table 2 は, Table 1 の条件における透視画像の視覚 評価を示したものである。

10年ほど前はアクリル $15 \mathrm{~cm}$ のファンムでは小ビ 一ズは見えなかった，消化管検査用X線TVでは，外径 $2.1 \mathrm{~mm}$ の小ビーズは見えなくてもいいと思う。

カッパメッシュや解像力チャートは透視画像に敏感 に反応していないことに気付いてほしい，両者はどこ の病院にでもあるものではない，そこで，試行錯誤の

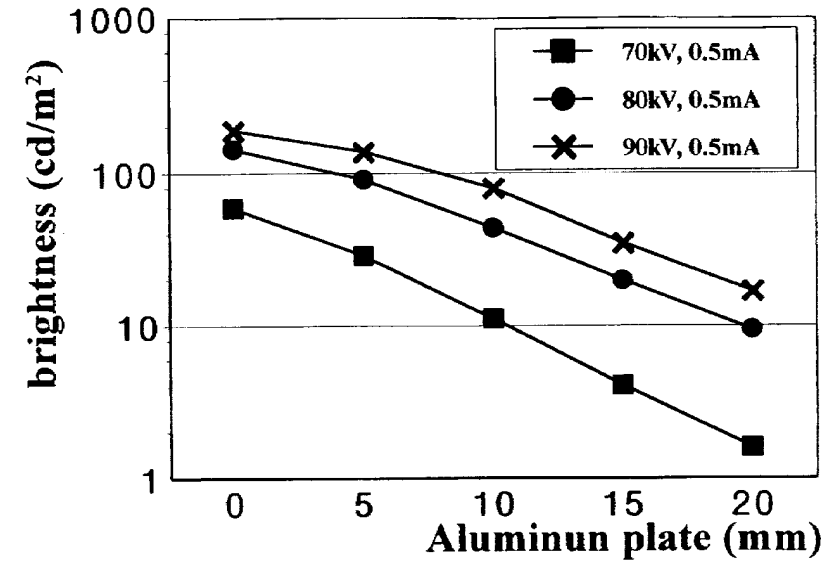

Fig. 21 The brightness of TV monitor based on the fluoroscopic conditions ('90). Excessive dose rate made the image on the TV monitor unclear in detail because of over-brightness. As the result, the worthless exposure increased.

末に有効なチャートを作った，普及のために本にも載 せ,メーカの工場にもあげた。このチャートは病院に あるものと無色のガラスビーズだけで作った．材料費 は数百円だ。台紙にビーズ等を貼りチャートとし、ア クリル板の代わりには目盛りを付けたプラスチックの バケツがあればなんとかなる．透視画像の経時変化を 見るには十分と考える。

この時ROC評価も行った。 ROC評価時の観察条件

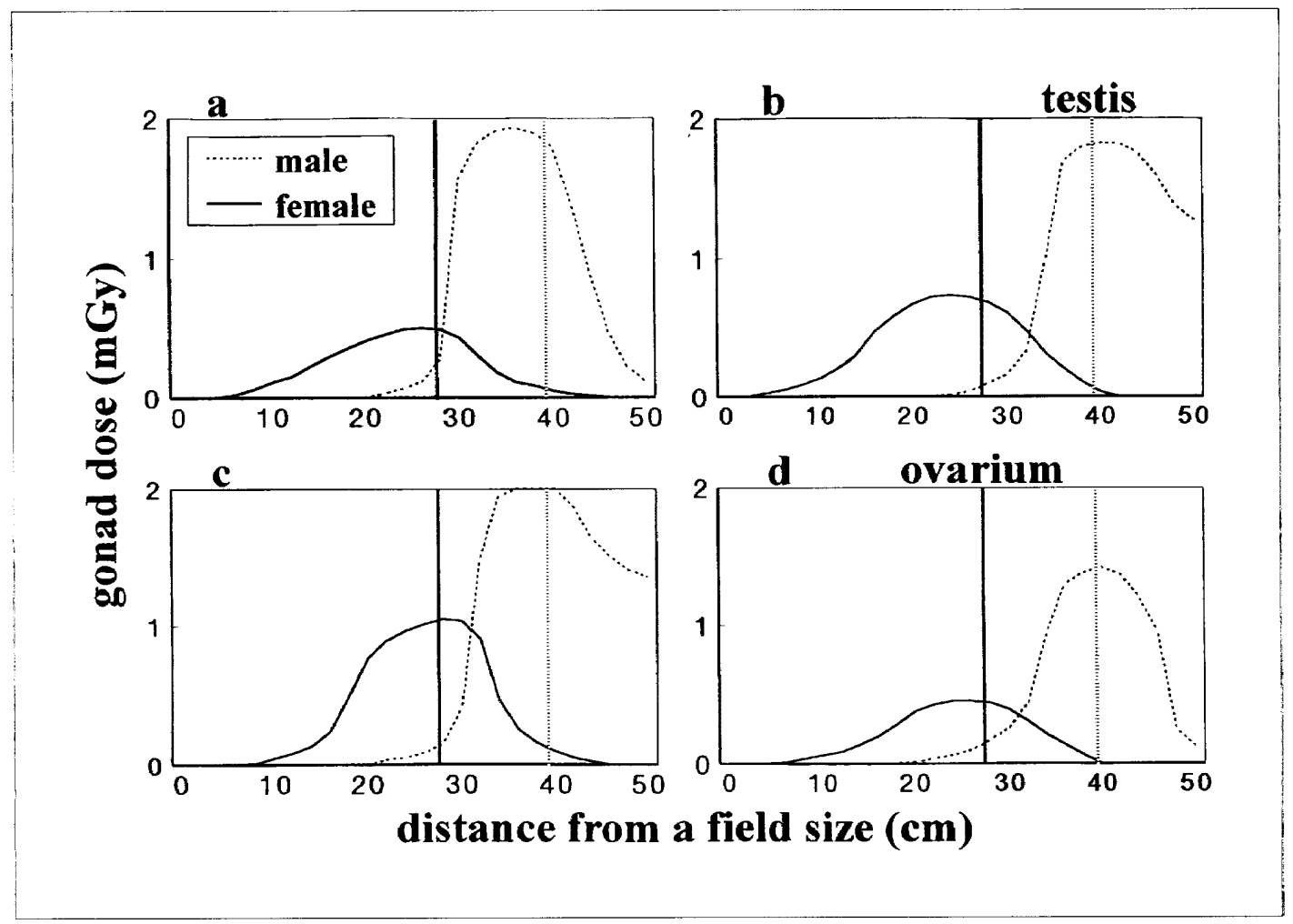

Fig. 22 Correlation between gonad dose and the exposure field in G.I. examinations ( $a$, $b$ : supine position, c,d: prone position). The comparison between fluoroscopy for fluorescent screen (a, c) and the over table tube type X-ray TV system (b, d) ('73). 


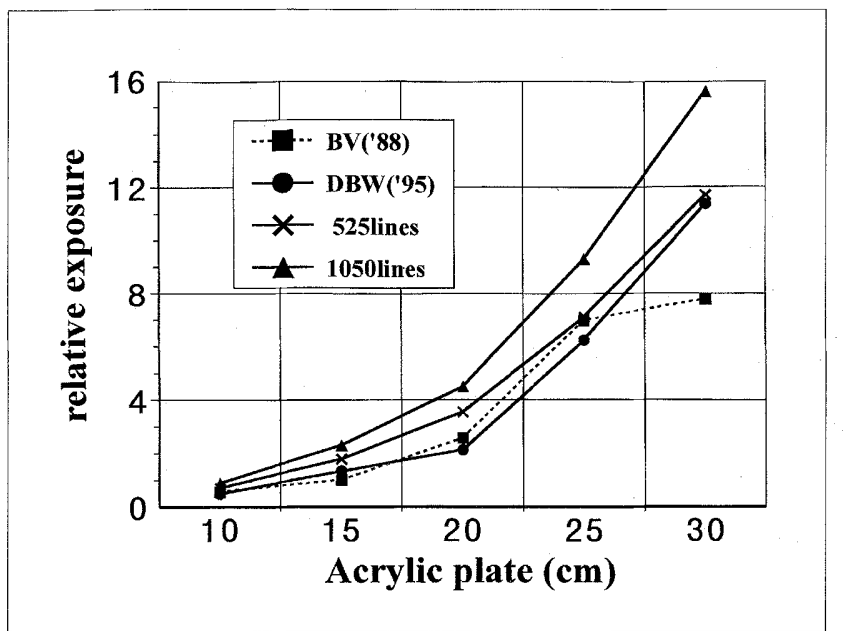

Fig. 23 Fluoroscopic conditions with an automatic brightness control. The relative air dose is normalized as 1.0 in the over table tube type X-ray TV type "BV" with an acrylic plate of $15 \mathrm{~cm}$ thick.

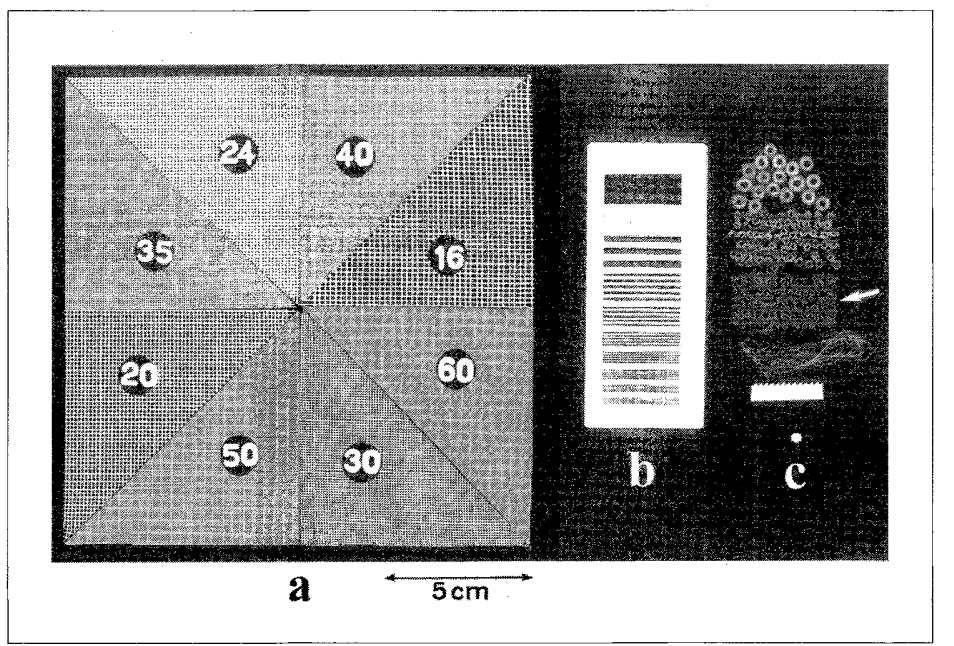

Fig. 24 The charts used for the visual evaluation of the fluoroscopic images.

(a) Copper meshes as a QC tool.

(b) A resolution chart.

(c) A custom-made chart; An arrow indicates $2.1 \mathrm{~mm}$ small beads in diameter.

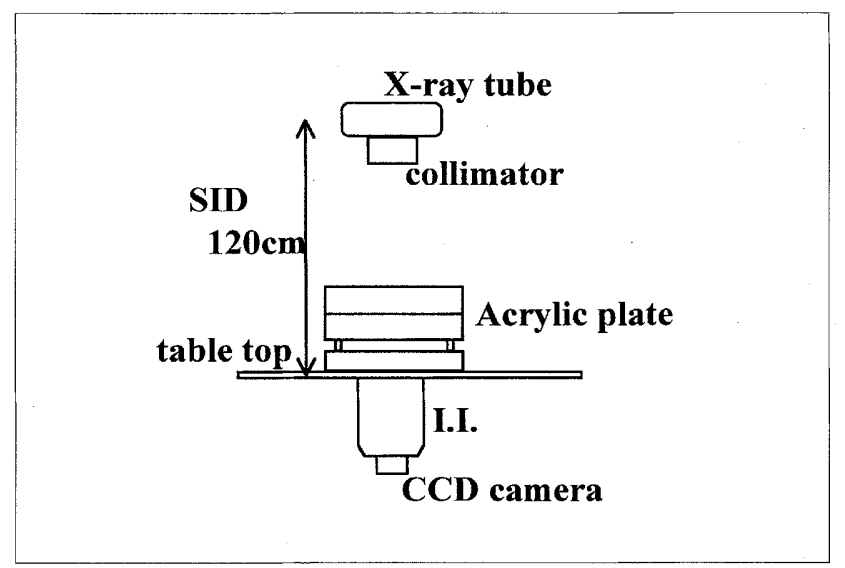

Fig. 25 An experimental illustration in two TV monitors evaluation with the over table tube type X-ray TV. $X$-ray focal spot size: $0.45 \mathrm{~mm} \times 0.43 \mathrm{~mm}$, antiscatter grid: $12: 1,40$ lines/cm, Al interspacer, coverless type, tabletop: wood in $9 \mathrm{~mm}$ thickness.
を以下に示した。

・観察時に室内は暗くした。

・ 1 試料の観察時間は40秒以内とした.

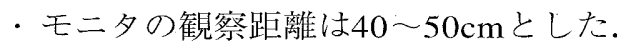

・トレーニングとして，ROC評価を行う前に，信 号を入れた画像を覚えてもらう.

・モニ夕を 4 分割してROC評洒を行い，前 面で視線解析をした。

・モニタの周辺部は使用しなかった.

・評価は 5 段階評洒とした。

1. 信号は絶対存在しない.

2. 信号はたぶん存在しないだろう.

3.どちらとも云えない. 判らない

4. 信号はたぶん存在するだろう。

5. 信号は絶対存在する。

視覚評価は誰でもできるものではなく訓練が 必要だ。ROC曲線はメッッ先生 ${ }^{12)}$ の ROCFIT を用いたＦig.26にTable 1 の条件における透 視画像のROC評洒を示した，走査線 525本TV と1,050本TVの比較で両者とも透視条件を下 げるとROC評価も下がった，雨者は高画質で あり，「ここまで見えなければいけないのか」 を検証しなければいけない。

数年前より透視画像, 胃X線検查の視線解 析に取り組んでいる。透視画像の評価をアイ カメラを用いて視線解析した。使用したX線 TVはオーバーチェーブでI.I.は古い.

Fig.27は上記のTVを使用し，アクリル $15 \mathrm{~cm}$ ，小ビーズを信号としたTV画面のROC評 価を示した。一言でいえば，信号はあまり見え なかった。そのため 5 段階評価の 5 と 1 がほ とんどなかった。

Fig.28は小ビーズによるROC評価時のアイ カメラによる停留点軌跡である．5段階評価 は停留点軌跡の下に示した。aのみはアクリル

Table 1 The comparison of fluoroscopic conditions with the automatic brightness control between 2 different types of TV monitors. This evaluation was conducted in TOSHIBA NASU works. The same X-ray tube and $X$-ray equipment are used. Over table tube type X-ray TV, 9 inch I.I. in diameter, SID $110 \mathrm{~cm}$.

\begin{tabular}{ccccc}
\hline & \multicolumn{2}{c}{ 525 lines/TV monitor } & \multicolumn{2}{c}{ 1,050 lines/TV monitor } \\
\hline acryl $(\mathrm{cm})$ & $(\mathrm{kV})$ & $(\mathrm{mA})$ & $(\mathrm{kV})$ & $(\mathrm{mA})$ \\
\hline 10 & 63 & 0.7 & 66 & 0.8 \\
15 & 76 & 1.2 & 80 & 1.4 \\
20 & 90 & 1.7 & 96 & 1.9 \\
25 & 108 & 2.4 & 117 & 2.7 \\
30 & 125 & 3.0 & 125 & 4.0 \\
\hline
\end{tabular}


$5 \mathrm{~cm}$ の条件で，くっきり信号が見えているの がわかる。 e, f は20秒観察，他は10秒だっ た（）内はROC評価時の 5 段階評価時の数 值である。見えにくい画像では，探している 視線となり個人差が出た。信号のない あたかも信号のある停留点軌跡を示し，観察 者は 4 と評洒している。gでは信号が視線と 別のところにある。評洒は 4 と正しい.アイ カメラの放射線画像への貢献はまだまだのよ うだ。

Fig.29aは，胃二重造影第二斜位で矢印の箇 所に早期胃癌があり，bは検査に熟練した放

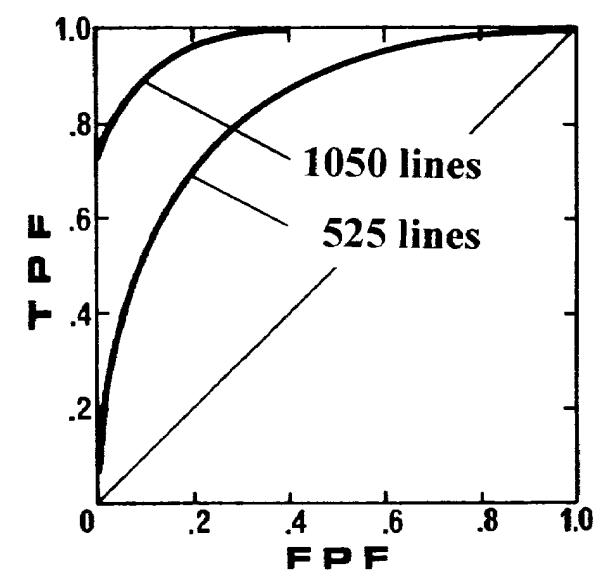

Fig. 26 The ROC evaluation of images on a 525 line TV monitor and a 1,050 line TV monitor. The lower the exposure conditions, the lower the ROC evaluation result on both TV monitors.
Table 2 The visual evaluation of fluoroscopic images on 2 different types of TV monitors based on the fluoroscopic exposure conditions are shown in the table 1.

\begin{tabular}{|c|c|c|c|c|c|c|c|c|c|c|}
\hline \multirow[b]{2}{*}{ acryl $(\mathrm{cm})$} & \multicolumn{5}{|c|}{525 lines/TV monitor } & \multicolumn{5}{|c|}{1,050 lines $/ T V$ monitor } \\
\hline & $\mathrm{S}$ & $M$ & $L$ & $\mathrm{Cu}$ & reso. & $S$ & M & $\mathrm{L}$ & $\mathrm{Cu}$ & reso. \\
\hline 10 & $\mathrm{O}$ & (O) & 0 & 30 & 1.50 & (O) & (O) & (a) & 40 & 2.00 \\
\hline 15 & $\triangle$ & 0 & $\mathrm{O}$ & 24 & 1.50 & $\triangle$ & (C) & (a) & 35 & 2.00 \\
\hline 20 & $x$ & $\triangle$ & $\mathrm{O}$ & 24 & 1.50 & $x$ & $\triangle$ & (O) & 35 & 1.50 \\
\hline 25 & $x$ & $\times$ & 0 & 20 & 1.25 & $x$ & $x$ & (O) & 30 & 1.50 \\
\hline 30 & $x$ & $x$ & $\mathrm{O}$ & 16 & 1.25 & $x$ & $x$ & $\mathrm{O}$ & 24 & 1.50 \\
\hline
\end{tabular}

$\begin{array}{ll}\bigcirc: \text { clearly visual } & \mathrm{S}, \mathrm{M}, \mathrm{L}: \text { bead size } \\ \mathrm{O}: \text { visual } & \mathrm{Cu}: \text { copper meshes (line } / \text { inch) } \\ \triangle: \text { poorly visual } & \text { reso. }: \text { resolution chart }(\mathrm{lp} / \mathrm{mm}) \\ \times: \text { invisual } & \end{array}$

$\times$ : invisual

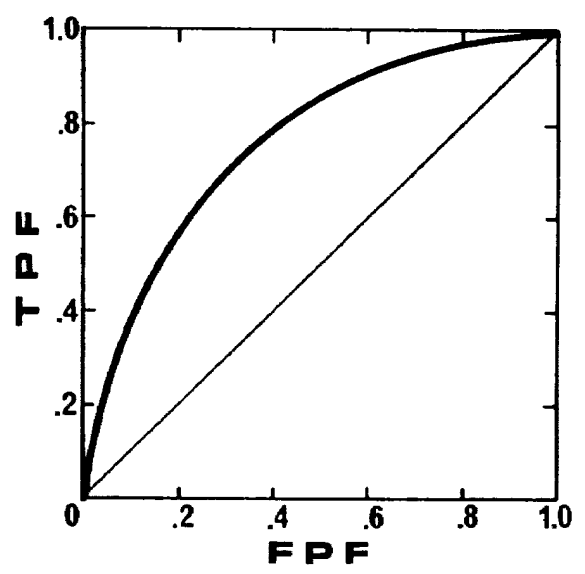

Fig. 27 The ROC evaluation of images on a secondhand monitor with small beads as signals and an acrylic plate of $15 \mathrm{~cm}$ thickness.

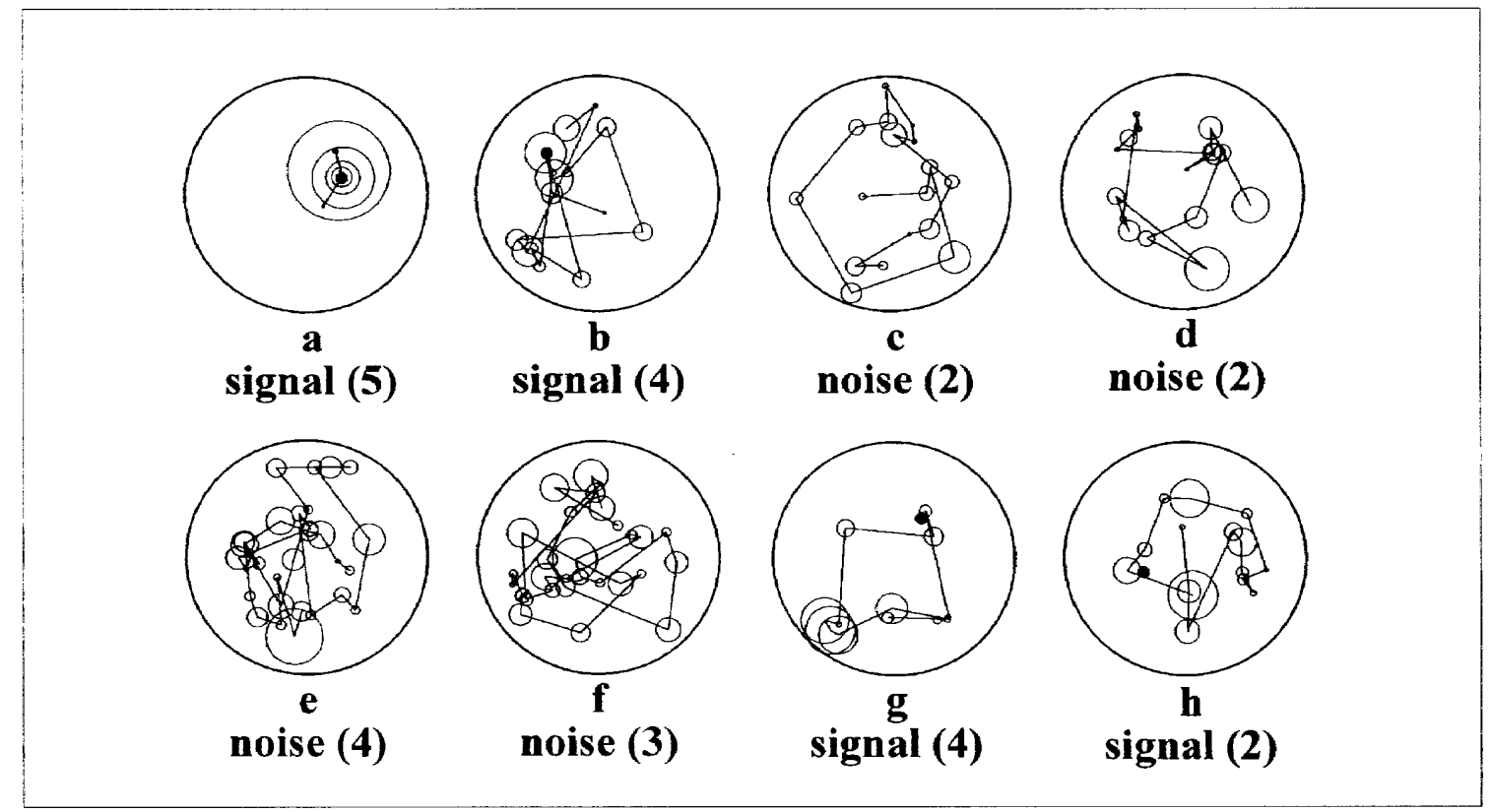

Fig. 28 Eye-fixation records of images on the secondhand monitor by an eye-camera. The observation time is 20 seconds in the graph e and $f$. That in the other graphs is 10 seconds. The figures in the parentheses indicate the values in 5 grades of the ROC evaluation. 


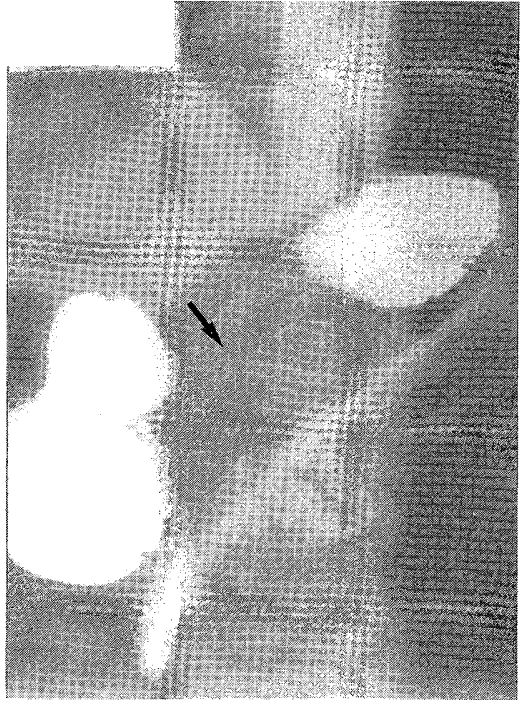

(a)

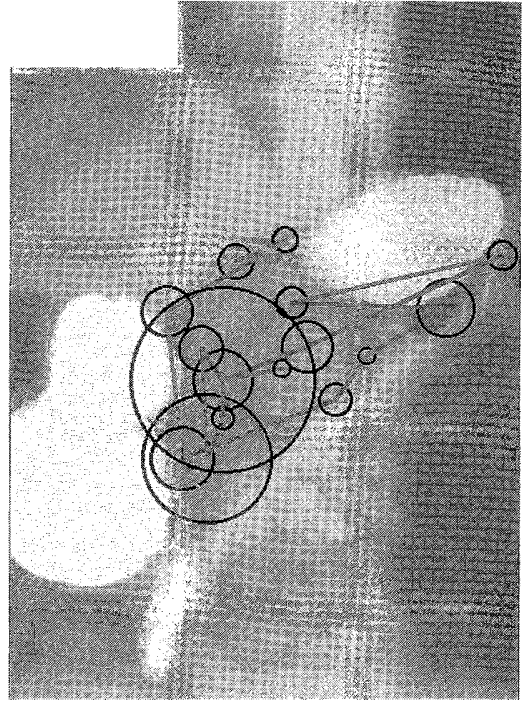

(b)

Fig. 29 The graph a has an early cancer pointed by the arrow in second oblique position of a upper G.I. double contrast examination. The graph $b$ shows eye-fixation records conducted by a skilled radiological technologist.

射線技師の停留点軌跡を示した．読影能力の高い観察 者の視線はまんべんなく二重造影部分を見ている。こ の研究はまだ始めたばかりだが，ROC評価より具体的 に観察者の脳と放射線画像を結びつけてくれると期待 し，続けていくつもりたシ。

\section{5. 考 察}

すばらしいことに, 本学会では1970年にX線テレビ ジョン特集号を発行している.内容も先見性がある.

私は長年にわたり，放射線機器のユーザとして，ま た工場の人との意見の交換のなか感じたことがある. 「こういうものが欲しい，こういうものはいらない」と いうのがユーザの役割で，放射線被曝低減は放射線科 医と診療放射線技師の責務と考えている。そのために は「これだけの画質で診断できるという画像の最適化」 が急がれる。また検查，診断する人の「質」は今回報告 の対象外であるが検査の最適化にはいちばん大切な部 分と考える。

アンダーチューブX線TVの消化管検查では画質と患 者被曝の面からできるかきりり速写板を患者に近づけて 検査すべきと考える。

メーカ側は，法規制のなかで，高画質の製品を作ろ うとするのは必然であり，線量を測って規制するのは ユーザの責任である。診断領域用の線量計を購入して ほしい.

一方，メーカ側はどのユーザのいう意見が正しいか を見極める必要がある。そのためには設計者は医療の 現場に通じていなければならない，また設計者はコン ピュータができるだけでは足りない，先人の知恵を受
け継ぎ，新しい機器のなかにその精神 をよみがえらせる必要がある。

X線管容量の足りないときは，陽極 側に濡れタオルを巻き検查した，増感 紙ーフイルムの組み合わせ感度，タイ マ，小焦点の目一杯の撮影条件を覚え て工夫した。撮影条件は写真濃度で適 正かどうか検証できた。 今もこの状態 の施設がある。しかし時代は変わって いっている，撮影，透視条件は自動化 が進み，X線TVのコントローラはマニ ユアル操作がほとんどできない機種が 増えている。透視も撮影もディジタル 化が進めば，いくらX線を過度に照射 しても，TVモニタもフィルムも適正 な輝度，濃度を保ってくれる，適切な 画質であっても，そのためにどれだけ X線を患者に照射したかを問われなけ ればならない。20年以上前に，患者の 大きさにより撮影管電圧が自動で変わるフォトタイマ のついたX線TVが作られた。私の考えでは撮影管電圧 を変えるのはユーザの技術であり，思想であるからと 反対した．被写体の薄いときは電圧が低いというもの だった，私の考えは，X線TVでは被写体の厚さに関わ らず，グリッドが同じであるから薄い被写体では管電 圧は高く，厚い被写体でも適正な管電压を変えないと いう考えである。薄い被写体では撮影管電流を下げる のだ。私の考えはすぐに設計者に伝わり，改良しても らえた。まず意見を言ってみなければ現状は変わらな い.

アナログ画像時代の消化管X線検査の最適化ができ てなければディジ夕ル時代の最適化はできないと考光 る。ディジタルの画像処理により同等の画像がどれた け少ないX線量で作れるかが画像技術の技術革新であ る.「同等の」という言葉を大切に考えている。「より 優れた画像」を追求すれば，技術革新は被曝低滅には 使われないと思う。現状では高画質のX線TVは高価格 で売れるし，メーカ間の競争にも勝てる．画質と透視 条件に差のある走査線 500本 TVと 1,000 本 TVでは価 格は 2 倍と聞いた。

最適化のなかに当然経済性も含まれるが今回の報告 ではまったく足りなかった、言い訳になるが「ここま での画質で診断できる」という問題が解決できないだ けでなく，定価と購入価の不可思議な世界で私にはお 手上げだった。同様にテクノロジーアセスメントにつ いての提案すらできなかった。 


\section{6. おわりに}

今これまでの部分を読み返すと，この報告の題名に は「私の」とつけて読んでいただかねばと思っている。 指導いただいた先達のご意見が入っていないと叱り を受けることを覚悟している．本学会の発表会で，20 年以上にわたり消化管X線唡査の画像技術の問題点を 提示し続けてきたが，少ししか評価されなかった。

私は放射線技術の激変期に技師として働き，技術革 新の試行錯䛊の時代に自分の考える装置を作ってもら えたこと, 増感紙一フルム系, フィルム処理にも意 見をいえたことを，恵まれていたと感じている，私の 願いは，有能なメーカのサービス員や放射線技師の意 見にもっと耳を傾けてほしいこと．医師の考えをメー カにわかる言葉に直して伝えてきた放射線技師は自分
の考えを持って，前を向いて提案してほしい，その姿 勢は，新しい制度で育つ後輩への励ましになると信じ ている。

\section{謝 辞}

稿を終えるにあたり，今回宿題報告の機会を与えて くださった関係役員の方々に感謝します。括話を聞か せていただき資料を下さった遠藤俊夫，佐藤 忠，萩 野谷透, 新居光廣氏はじめ多くの力々, 数十年にわた りご支援くださったメ一カの方々，ありがとうござい ました。この研究の一部はがん研究助成金鳥脇班(名 古屋大学 鳥脇純一郎教授) と, 科学技術調整費によ る生活・地域流動研究(オーガナイザ：京都府立医科 大学 前田知穂教授)の援助を受けたものです。

\section{参考文献}

1) 熊倉賢二：臨床医の求める胃部X線写真の画質とは。日放 技学誌，51(11)，1655-1660，(1995)。

2) 佐藤 忠：良い胃部造影画像を構成する基本について. 日 放技学誌，52(3)，435-439，(1996).

3) 堤 直葉, 川村義彦, 中西省三, 他: 增感紙一フィルムに ついてのアンケート集粷一. 日放技学誌, 38(2)，219226, (1982).

4) 堤 直葉, 川村義彦, 中西省三, 他: 撮影技術委員会, 増 感紙娭討班報告. 日放技学誌，38(6)，891-898，(1982）。

5) 斉藤一彦, 堤 直葉, 宮崎 茂, 他: 撮影系実態調查集計 報告。日放技学誌，43(3)，417-439，(1987)。

6) 堤 直葉, 中西省三, 川村義彦, 他: 撮影系実態調査報告 (その1)-X線撮影系とCRについてのアンケート集約一. 日放技学誌，48(10)，1884-1903，(1992）.

7) JISハンドブック放射線（能）1996：日本規格協会, (1996).

8)堤 直葉, 阿部正己, 染谷武男, 他: The characteristics of medical $x$-ray films and the effect of the silver content on image

quality.日放技学誌，44(11)，1575-1582，(1988）。

9) 堤 直葉, 宇佐美達也：胃X線唡査における患者の生殖腺 被曝線量, 日放技学誌, 28(1)，(1972).

10）堤 直葉, 宇佐美達也：腸X線娭查における患者の生殖腺 被曝線量. 日放技学誌, 29(1)，46-51，(1973）。

11 ) 堤 直葉：装置と記録系編，放射線技師のための消化管撮 影技術(第2版)，pp.165-188，金原出版，東京，(1986).

12) ディジタル画像のROC解析検討班編：ROC解析の基礎と㐫 用, 放射線医療技術学叢書 $(8)$, 日本放射線技術学会, (1994).

13) X線テレビジョン特集, 日放技学誌, 特輯第 5 号, (1970).

14) Medica Mundi: Philips Medical Systems, 40(3), (1995).

15) TOSHIBA MEDICAL REVIEW，20，(1987）：医療上健康 と共に，東芝メディカル総業58年・設立40年の歩み。東芝 メディカル株式会社，（1988）。

16)レントゲン回顧：島津製作所, (1994).

Anton

Fig. 1 越谷市立病院に扔ける胃腸検査件数の推移. 胃の減少は全国的な傾向である.

Fig. 2 阪南中央病院の遠隔オーバーチューブX線TVによる胃X線検查における4医師による透視時間の比較. 撮影枚数の平均は 8.4 枚。透視時間も短い('76一’77).

Fig. 3 越谷市立病院の胃X線枱查に扔ける透視時間と撮影枚数(の関係)について。近接(local)アンダーチューブ型X線TV(’80ー '81).

Fig. 4 越谷市立病院の胃X線蚞査に扔ける透視時間と撮影枚数について('94〜95). 全機種のルチン検查全体.

Fig. 52 機種の近接X線TVのMTFの比較('79).

Fig. 6 実態調査による撮影電圧の推移, 撮影電圧は装置の表示值.Fig.6，8，10，12，13は実態調査のデータを用いた。

Fig. 7撮影電压のアルミニウム透過曲線による比較。測定はnarrow beamで行った。現在はインバータが主流である.

Fig. 8 X線管焦点サイズ(公称值)で，焦点サイズの統一化が進んでいる.

Fig. 9 X線管焦点サイズは公称值が通用しているが，実効焦点との差は大きく，JISの許容範囲からも分かる．画質は焦点の面積 に依存するので繸軸は焦点面積で表した。

Fig. 10 増感紙-フィルム系の使用比率の推移.ブルーからグリーンシステムへの移行はX線TVシステムでは早かった.

Fig. 11 実態調査で頻度の高い増感紙-フイルム系のMTF.この図ではグリーンシステムはHR-4+オルソフイルムの組合せが多く, ブルーシステムでは点線のBM III+NewRXが多かった('90).

Fig. 12 䒠態調査で使用されている増感紙-フィルム系の相対感度をブルーとグリーンシステムに分けて, その施設数比を示したも ので, 調查初期に多かったMSクラス增感紙+NewRXを基準とした.

1998 年 3 月 
Fig. 13 Fig.12のデータを用いて推定線量を計算したもので, 増感紙-フィルム系の感度が同じでも施設間の線量の差は大きかった。

Fig. $1478 \sim 82$ に本学会に発表した增感祇の变性. 増感祇の保護膜の損傷により，その部分が減感した。この問題は全国的に発生 し, X線TVに装着した増感媇で多発した。

Fig. 15 フィルムチェンジャタイプのX線TVの初期の機種では增感紙フフィムの密着に時間がかかりX線写真の鮮鋭度が覀くなっ た('83)。絴軸はハウレットチャートの読み值と，解像力チャーートの読み值. 横軸はフィルム装填スイッチを押してからの 経過時間(秒).

Fig. 16 フィルム名，使用期限と含有銀量 $\left(\mathrm{mg} / \mathrm{cm}^{2}\right)$ ( $(88)$.

Fig. 17 低濃度部に扔けるハウレットチャートによる視覚評価(撮影条件 $70 \mathrm{kV}$ ，グリッドあり，ファントムはアクリル10cm).

Fig. 18 自動露出機構の娭出部の比較.

Fig. 19 バリウムの被覆率に対する線量比. 円内はTV画面のバリウム被覆率を示す.

Fig. 20 アンダーチューブTVの速写部を患者から唯したときと密着したときの透視条件の違い.バリウムがない状態では60kV， $0.5 \mathrm{~mA}$ であった。

Fig. 21 透視条件の変化とTV画面の揮度の関係, 適正な透視条件考超えると画面は明るすぎて見えなくなり，無駄な被曝が增える ('90).

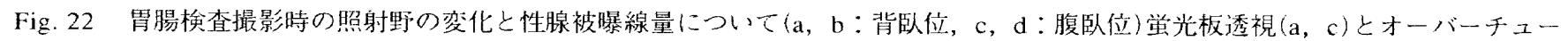
ブX線TV(b, d)の比較('73).

Fig. 23 自動輝度調整機構 (auto brightness control)を使用した透視条件.オーバーチューブタイプで88年機種BVにおいて，アクリ ル $15 \mathrm{~cm}$ の条件を 1.0 上した。維軸は空中線量比(relative air dose)

Fig. 24 透視画像の視覚評洒に用いたチャート，a はQCツールのカッバメッシュ(䞒の網)， c は自作の透視用チヤート，矢印は実 騃に用いた小ビーズ。大きは外径 $2.1 \mathrm{~mm}, \mathrm{~b}$ は解像力チャート.

Fig. 252 種のTV画像の評価時の赛験図, オーバーチューブタイプX線TV，X線管焦点： $0.45 \times 0.43 \mathrm{~mm}$, 散乱線除去グリッド：12：1, 40 本 $/ \mathrm{cm}$ ，インタースペイサーAlでカバーレスタイプ．天板は木製で厚さ $9 \mathrm{~mm}$.

Fig. 26 Table 1の条件におうける透視画像のROC評価. 走査線 525 本TVと1,050本TVの比較，両者は条件を下げるとROC評価も下 がった.

Fig. 27 古い, 透視条件の少ない装置のアクリル15cm, 小ビーズを信号としたTV画面のROC評洒.

Fig. 28 Fig.28の実験時の続き。アイカメラで透視画像観察時の停留点軌跡を示した。e,fは20秒観察, 他は10秒だった。(）内 はROC評洒時の 5 段階評洒時の数值.

Fig. 29 (a)は, 胃二重造影第二斜位で矢印の箇所に早期癌があり，(b)は検查に熟練した放射線技師の停留点軌跡を示した。

Table 1 自動輠度調整譏構を使用した透視条件, 東芝那須工場で2 種のTV系は同じX線管, 発生装置を用いた。オーバ一チューブ タイプ, I.I.は 9 インチ, SIDは110cm.

Table 2 Table 1 の条件に拂唀視画像の視覚評価. 